\title{
Ssciendo
}

Ethics \& Bioethics (in Central Europe), 2021, 11 (3-4), 142-152

DOI:10.2478/ebce-2021-0013

\section{Triage of the elderly in the period of the COVID-19 pandemic crisis as a bioethical process}

\author{
Rudolf Novotný, ${ }^{1}$ Zuzana Novotná, ${ }^{2}$ Štefánia Andrašč́́ková ${ }^{3}$ \& Peter Firment $^{4}$
}

\begin{abstract}
The paper discusses the problem of triaging the elderly in the period of the COVID-19 pandemic crisis by analyzing the triage process, caused by lack of resources, in Germany, Holland, the Czech Republic, and Slovakia. We apply inductive, deductive, and normative bioethical methods, comment on various recommendations for the indication of intensive care during a crisis, and discuss the utilitarianism of benefit maximization. As it follows from the evaluation of the elderly by the frailty parameter, medically inappropriate treatment, as a result of limited resources, is characterized by clinical and bioethical uncertainty. If the main bioethical objective of general bioethics for the COVID-19 pandemic is, in the case of limited resources, based on the non-utilitarian consequentialism paradigm, from the perspective of medical ethics, we face a borderline situation closely related to the topic of dying and death. Such a situation requires social, ethical, and professional reflection. An algorithm for intensive care indication in the situation of crisis and limited resources in the period of the pandemic requires a definition of criteria that identify an acceptable reason for abandoning the treatment in the context of the autonomy of the elderly and by respecting their human dignity and humanity. A global objective of general bioethics in the situation of the pandemic crisis should be based on the paradigm of social justice.
\end{abstract}

Keywords: bioethics, COVID-19, elderly, utilitarianism, frailty, medically inappropriate treatment

\section{Introduction}

The World Health Organization classified COVID-19 caused by SARS-CoV-2 as a pandemic on $11^{\text {th }}$ March 2020. The pandemic caused by the new-discovered SARS-CoV-2 coronavirus brings about professional and ethical dilemmas concerning limited medical resources all over the world. In crises, such as pandemic situations, the decision-making processes significantly change if health care resources are insufficient. National and international medical and bioethical institutions worked out recommendations for addressing the problem of insufficient resources for acute health care. Triage in crises concerns the selection of patients for medical treatment, which means that those who are not selected do not have to be provided with any useful treatment. Triage decisions in a crisis are usually based on the specification of medical urgency priorities, the ability to utilize available resources, evaluation of short-term vs. longterm prognoses, including the role of age and comorbidities as potential triage criteria. Consistent and fair decisions depend on the definition of clear and transparent criteria for maximizing the benefits in triage situations.

\section{Bioethics and the pandemic}

The bioethical perspective of health care during a pandemic crisis requires an analysis of changes in medical ethics that are conditioned by the pandemic situation in a crisis due to the lack of scarce resources. If the fundamental change in the philosophical paradigm in the pandemic period stems from the requirement of maximum benefits in providing intensive health care, we are dealing with a utilitarian requirement. This is specified in relevant ethical considerations and recommendations of professional institutions. Utilitarianism refers to several possible interpretations related to the problem of dying and death. Philosophy seeks

\footnotetext{
${ }^{1}$ Faculty hospital of J. A. Rayman in Prešov (Slovakia); novotny.r@fnsppresov.sk; ORCID: 0000-0002-43633954

${ }^{2}$ University of Prešov (Slovakia); ORCID: 0000-0002-2034-5124

${ }^{3}$ University of Prešov (Slovakia); ORCID: 0000-0001-7960-6168

${ }^{4}$ Faculty hospital of J. A. Rayman in Prešov (Slovakia); ORCID: 0000-0002-3061-2003
} 
a solution for the main principle of benefit maximization in the non-utilitarian ethics of social consequences that also reflects the medicine of disasters (Gluchman, 2016). The population of the elderly (from the point of view of the age and frailty as well as potential incompetence and absence of information for various bio-psycho-social reasons) is an extremely endangered group whose autonomy, respect for human dignity and a human approach must also be observed in the pandemic period.

Bioethical principlism is completed and partially replaced with new, dominant 'crisis principles'. Specific situations in which the patient's autonomy is relevant must be well defined. The situation of a crisis or disaster cannot relativize the patient's autonomy. We point out the internal dimension of autonomy. The significance of human dignity in the form of respect for a patient is highlighted in crisis situations. From the consequentialist perspective, equal treatment of patients may hamper the best possible results; from the deontological perspective, the maximization of benefits may result in discrimination or violation of a person's rights. The basic ethical problem is how to combine both perspectives and respect a person's rights. A consequent utilitarian approach based on the maximization of saved years of life is not convincing. It is important to save the greatest number of lives possible without violation of patients' rights.

\section{Medically inappropriate treatment in the pandemic period}

The basic communication tools that bridge professional and ethical pandemic dimensions are the content of professional terminology. This section deals with the notion of 'medically inappropriate treatment' because an expert-ethical analysis demonstrates the impossibility to preserve the patient's autonomy in the case of a medical decision of medically inappropriate treatment. The paper demonstrates that autonomy cannot be relativized, its extent must be precisely applied to concrete clinical situations also in the case of reduced reasons for the patient's autonomy in the period of disaster. European recommendations for health care triage in the COVID-19 pandemic situation for which there is no medical indication substantially vary in terms of the terminology used. Austrian and German recommendations employ the term 'medical indication', Italian recommendations use 'clinical appropriateness' and 'proportionality', and Belgian authors use the term 'inadequate care' meant for "patients with unfavourable long-term expectations." According to Swiss recommendations, a doctor must first determine the necessity of intensive care which can be interpreted as a synonym to medical indication (Ehni, Wiesing \& Ranisch, 2020).

In the period of a pandemic, in connection with lack of medical resources in the absence of health care, the indication of medically inappropriate treatment prevails, in the case of classification decisions in a situation of lack of resources, the prioritization criteria depend mainly on value systems. These are borderline processes (Šustek \& Černý, 2021).

Futile treatment from the point of view of a patient's benefit does not lead to saving a life, preserving health, or maintaining the quality of life. From an ethical point of view, medicine is not expected to provide futile treatment (Kuře, 2020). Futile treatment can be evaluated in terms of quantitative, qualitative, and physiological futility. Quantitative futility expresses the measure of the probability of a positive change in a patient's condition as a result of treatment. The quantitative futility method does not authorize a doctor to decide on the success/failure probability degree that is meaningful/meaningless for the patient. Any effort to do so would contradict the patient's autonomy. Qualitative futility is a treatment that does not meet its objectives or is incompatible with them and does not improve the patient's quality of life. In qualitative futility, a doctor cannot estimate the degree of fulfillment of the patient's objectives that still make sense for the patient. Physiological futility refers to the patient's situation in which the condition of the physiological systems cannot be reversed by any available medical intervention. Unlike the former two futile treatments, physiologically futile treatment may be 
exclusively determined by a doctor because he was trained to assess whether a proposed treatment may achieve physiological objectives. Compared to the ethical-expert assessment of treatment futility which also includes the patient's preferences, medically inappropriate treatment is assessed by a doctor owing to their relevant education. If a doctor evaluates the medical appropriateness, its adequacy refers to the disease, its extent, and/or symptoms; it does not refer to the therapeutical objective (Novotný, Novotná \& Andrašč́ková, 2020).

The medical appropriateness for universal patient triage (not only the COVID-19 pandemic), should be determined as follows:

1. quantitative medical appropriateness should be considered on the basis of an organ system failure despite adequate treatment of the associated serious palliative diseases, or in the case of terminal condition.

2. qualitative medical appropriateness should be considered based on the clinical condition progression and worsened syndromology, which affects the quality of life (geriatric patient based on geriatric deterioration).

3. Physiological medical appropriateness should be considered based on the frailty index if the condition of the patient's physiological systems in the terminal stage of frailty cannot be reversed by any available medical intervention.

The proposed understanding of the concept of 'medically inappropriate treatment' excludes the patients' preferences and their quality of life from the criteria that are generally used as futile treatment criteria. If, in an acute condition, a doctor assesses the chronically ill patient's condition primarily based on the possibility of medical intervention without assessing the overall patient's condition (by reflecting the disease stage, disease extent, the severity of clinical symptoms) medically inappropriate treatment as a reason for discontinuation of treatment cannot be accepted. It may be assumed that triage scoring systems are more consistent compared to clinical judgments for the doctor's decision-making. The severity of acute disease should be determined by a combination of clinical and laboratory findings and by means of scoring indexes (Feinstein et al., 2020).

Two main principles underlie the normative basis for patient triage recommendations: fairness and benefit maximization. The fairness principle means that all patients with a comparable prognosis should be provided equal access to the necessary medical care in the period of crisis on the basis of medical and ethical criteria to be specified in advance. The benefit maximization principle in the condition of shortage may refer to various situations: saving as many people as possible, saving as many years of life as possible, saving as many years of life as possible in terms of the quality of life (QALY - Quality-AdjustedLife-Years). Resource allocation heavily depends on the criterion applied. The principle of the maximum number of years of life considers comorbidities, makes use of validated prognostic models, for example, frailty score and the comorbidity index modifications proposed by Charlson. Young people would benefit from saving as many years of life as possible; on the other hand, people capable of living a long, healthy, and independent life would benefit from the QALY maximization. The principle of maximization of the number of lives makes use of 'acute' indexes, primarily the SOFA index (Sequential Organ Failure Assesment). The evaluation of the possibility that a patient leaves a hospital alive takes into consideration the course of the COVID-19 disease as well as accompanying potentially adverse prognostic factors (White et al., 2009; White \& Lo, 2020).

Age is a controversial factor in triage models. The question is whether elderly patients are unfairly disadvantaged. One of the arguments is that age is also used in frailty indexes. The concept of frailty is, however, related to biological age. It does not correlate with chronological age. Earlier research has proved that the clinical frailty score and chronological age are independent entities. High chronological age is in itself an independent predictor of a bad result 
of intensive care for both COVID-19 patients and non-COVID-19 patients (White et al., 2009; White \& Lo, 2020).

An ethical analysis of international recommendations for COVID-19 triage suggests that all documents agree on the fact that the age itself is not sufficient as a criterion for deciding on triage. The age must correlate with comorbidities and a prognosis. Most of the documents mention long-term prognoses as a decision-making criterion for triage. Inherent age and comorbidity are considered crucial factors. The frailty scale and the degree of comorbidities in elderly people are recommended as a tool for the determination of a prognosis by various national recommendations. The inclusion of comorbidities (through the frailty index) is not only more advantageous for younger patients compared to elderly patients but also for people without health problems compared to people suffering from health problems. Consequently, there is an unambiguous tension between the maximization of benefits and the focus on nondiscrimination of those groups that are characterized by frailer health. This should be evaluated as a situation of bioethical uncertainty.

Fairness and maximization of benefits should be the core triage principles. The principle of fairness: non-discrimination by age, race, health problems, sexual orientation, religion, insurance, wealth, social status; adequate attention should be paid to vulnerable groups (the elderly, minorities, handicapped people).

The principle of maximization of benefits: We need an unambiguous definition of the maximization of benefits in various stages of deficiency. It is important to distinguish between first-order criteria (e.g., short-term survival) and second-order criteria (e.g., long-term survival). Recommendations concentrate on the maximization of benefits from "saved lives" or "saved years of life." The quality of the saved years of life is not explicitly mentioned. Most of the recommendations specify parameters for short-term and long-term prognoses (Germany, UK, USA). All recommendation documents comprise health criteria for triage decisions. We need a comprehensive evaluation of short-term and/or long-term survival by medical criteria, tests, and validated prediction scoring systems. Various scores are recommended for the evaluation of death risk and estimation of survival probability of the acute condition. Some of the recommendations employ the SOFA score (Germany), others reject it because it was not validated for the SARS-CoV-2 pandemic (USA).

Principle of equality: Professional-ethical considerations of triage comprise all patients, both current and new ones, and both COVID-19 patients and all non-COVID-19 patients.

The principle of transparent decision-making, explicitly specified in the majority of recommendations, enables patients and their relatives to understand the process of clinical decision-making. Transparency is defined as providing information for public access. No recommendation proposes the specification of priorities based on merits or social status (Jöbges et al., 2020).

\section{German recommendations for triage in the period of a pandemic crisis}

German decisions of intensive care resource allocation in connection with the COVID-19 pandemic are clinical and ethical recommendations. They were elaborated by a multidisciplinary group of authors supported by eight scientific medical societies. The recommendations were proposed by experts from clinical urgent medicine, intensive medicine, medical ethics, law, and other areas of science. The recommendations stress that medical decisions must always reflect the needs of a concrete patient. In addition to this patient-oriented approach, the determination of priorities in the situation of resource deficiency presupposes a super-individual perspective. Decisions of the allocation of limited resources must be taken analogically to triage decisions in the medicine of disasters. The specification of priorities does not explicitly pursue the objective of assessing the value of people or human lives. The specification of priorities should rather enable the maximum possible number of patients to 
make use of (limited) medical resources in the conditions of a pandemic crisis. The determination of priorities regarding patients should therefore stem from the criterion of clinical chances for success. Patients with better chances to survive after intensive care should be prioritized (indexes SOFA, APACHE II - Acute Physiology and Chronic Health Evaluation II, CRB-65 - Score for Pneumonia Severity, ECOG - Eastern Cooperative Oncology Group, Performance Status). The principle of equality does not permit any priorities derived from calendar age, social characteristics, specific diseases, or handicaps. The specified diseases and conditions (seriousness of the main disease or injury and the stage of serious comorbidities that reduce the probability of surviving intensive treatment, overall health condition before the present disease, for example, according to the clinical frailty scale as a part of geriatric evaluation) are not exclusion criteria - in contrast to other triage protocols.

Overall evaluation should take into consideration all important factors that affect the chances for success (present disease, comorbidities, general health condition). Former diseases are relevant only if they influence the probability of survival concerning the present disease (Marckmann et al., 2020).

\section{Dutch recommendations for triage in the period of a pandemic crisis}

As the first step towards a stricter triage protocol, the Dutch Intensive Care Society (Nederlandse Verenigingvoor Intensive Care - NVIC) formulated various levels of medical criteria strictness for patients considered for intensive care (NVIC, 2020). The exclusion criteria were formulated in accordance with the CHEST consensus declaration (Christian et al., 2014) based on a low probability of survival and short life expectancy. The Dutch ethical recommendations for the COVID-19 intensive care protocol emphasize an early interaction between clinical and ethical expertise. Tailor-made ethical recommendations can and must be employed at the time of a crisis.

Every human being has an equal moral value. A justified triage objective at intensive care units is saving the greatest possible number of lives. Triage based on mental and physical disorders or indexes of the former life quality was rejected because every human being has the same moral value, and every life is worth saving. Medical criteria, such as the clinical frailty score (De Geer, Fredrikson \& Tibblin, 2020), were used as a factor for the determination of the probability of survival in former triage steps, which means that there are no additional reasons for their use in deciding on scarce resource allocation. Age as a priority criterion is relevant for patients whose condition is worst. If it is not possible to save all lives, the position of young people is relatively worse than that of people who have been living their life longer (fair change). Age as such should not be a criterion. What matters is a sufficiently large difference between patients belonging to different intergeneration categories. This is best captured by the term 'generations' that can be used to refer to intergeneration solidarity. Many elderly Dutch citizens stated during the first weeks of the pandemic that they were ready to give up their claim to an ICU (Intensive Care Unit) bed if it could save the life of a younger person. Consultations with various groups of patients and elderly citizens showed that the 'generation' argument was positively accepted and considered as justified. Age is a relevant criterion in terms of intergeneration solidarity. Based on their age, people are classified as members of a generation. Younger generations have a higher priority than the older generations. Generations are defined as the following age groups: $0-20,21-40,41-60,61-80$, and $81+$. Holland reached a social agreement on the fundamental idea of a fair change, which means that younger people are more authorized to life-saving intervention. The conception of a fair change cannot be considered as discrimination of elderly people.

Dutch bioethicists contributed to the rejection of the idea of using age (e.g., $>80$ years or even $>70$ years) as a criterion for absolute exclusion in triage. As a result, the score of clinical 
frailty is not used for elderly people because it might lead to unfair discrimination of a person with former mental or physical disorders (Verweij et al., 2020).

\section{Czech views and instructions for triage in the period of a pandemic crisis}

The Czech recommendations Ethical and legal principles for making decisions on scarce resource allocation in providing health care during the COVID-19 pandemic is based on, among others, the following tenets: Reference to the philosophy of utilitarianism; maximization of benefits by the number of saved lives; the principle of respect for autonomy is backgrounded at the period of crisis; ethics permits the making of decisions on the basis of age and to prioritize younger patients (death would be worse for them than for older patients); it is not age-based discrimination; age is not a triage criterion - it is a variable that determines the degree of evil caused by death (Černý, Doležal \& Doležal, 2020).

Jedličková (2020) maintains that the above-mentioned document by Černý, Doležal \& Doležal (2020) specifies four principles of scarce resource allocation. They are identical to the ethical aspects of decision-making included in the recommendations published by the World Health Organization (WHO, 2020). The document states that prioritization should be targeted at those at greatest risk of becoming infected and seriously ill who, however, have a real chance to survive or those who, in the case of death, would live a short life (young patients). She points out that the WHO recommendations do not mention priority-setting by age (Prioritize the worst off). On the contrary, the WHO documents unambiguously stress that since this pandemic most seriously affects elderly patients, the priority-setting in scarce resource allocation might lead to an inappropriate application of triage instructions based on age limits thus excluding elderly patients from treatment (WHO, 2020). The author concludes that the four proposed principles of scarce resource allocation should neither replace the four basic ethical principles of medical practice nor modify them. Some practical aspects could, if necessary, complement them in strict compliance with all legislation.

The Standpoint of the committee of the Czech Society of Anaesthesiology and Intensive Care Medicine ČLS JEP (ČSARIM and ČSIM) (ČSARIM, 2020) labeled as Decision-making on intensive care patients in the situation of the lack of scarce resources mentions bioethical principlism, individualizes the beneficence principle, selects the autonomy principle, and emphasizes the human dignity of patients. Any discrimination (disability, age, etc.) is unacceptable. The Standpoint identifies basic ethical principles of scarce resource allocation in crisis situations (fairness, maximum benefit, prioritization); the life expectancy criterion, in its view, contradicts the legal system of the Czech Republic. The benefit maximization is assessed on the basis of maximum medical benefit for the greatest number of patients possible. The decision of admitting a patient to an Intensive Care Unit (ICU) should be based on the principles specified in the Standpoint of the ČSARIM and ČSIM committee dated 2015. The reasons for non-admission to intensive care or the termination of intensive care should result from a comprehensive evaluation of the overall clinical context. An expert view cannot be replaced in this case with any scoring system or numerical parameter. Treatment can be terminated without comparison to any other patient if an expert assessment finds it the medically inappropriate (ČSARIM, 2015).

In the Czech Republic, the expert, (bio)ethical, and legal views of health care during the COVID-19 pandemic differ in terms of scarce resource allocation. No consensual recommendations of triage have been approved. Comments emphasize the legal and ethical uncertainty of doctors in this situation, this being an important aspect that is not accentuated in the recommendations of other countries (Šustek \& Černý, 2021). 


\section{Slovak recommendations for triage in the period of a pandemic crisis}

Slovak recommendations were published as Expert guidance of the Ministry of Health for intensive care indication in a crisis due to the COVID-19 pandemic in March 2021. It was published in the periodical of the Ministry of Health (Ministry of Health of the Slovak Republic, 2020). The text is divided into paragraphs. Paragraph II specifies medical, ethical, and legal principles. It refers to the tables (Table 1: Terminological dictionary, Table 2: Principles of medical triage decision-making, Table 3: Ethical triage principles) that provide general medical and ethical principles. Paragraph IV specifies the triage procedure. The triage process should be preceded by an assessment of a patient's condition in terms of an intensive care indication. Table 4 specifies the intensive care indication. Diagram 1 is an aid for decisions on triage for intensive care indication. Table I concerns comorbidity, Table II frailty, and Table III provides the total score complied from Tables I and II. The total score equal to or exceeding 8 indicates acute care (ICU or Anesthesiology and Intensive Care Unit); the total score of 9 and more indicates conservative care; the total score equal to or higher than 11 indicates palliative care. For illustration, Table II Frailty (defined as "a description preceding an acute condition") assigns 9 points to terminal patients approaching the end of life, which means, they are not expected to stay alive for more than six months even if they are not evidently frail.

The Terminological dictionary of the expert guidance (Table 1) defines the term 'unyielding treatment' (synonymous with futile, inadequate, medically non-indicated treatment). It should be noted that the term 'futile treatment' lacks a corresponding expert-ethical context in the case of a limited capacity for intensive care indications, and therefore, the term 'medically inappropriate treatment' is used for triage.

Medically inappropriate treatment concerns not only the decision on what will not be provided but also on what will be provided. Consequently, the governing decision-making principle is the objective of health care. A selected means is medically appropriate if the normative criterion for a change in the doctor's procedure is in harmony with the objectives of health care (teleologically, its harmony with the specified purpose) (Černý, Doležal \& Doležal, 2020).

Tasks and objectives of a bioethical process and triage in the period of a pandemic crisis Contemporary bioethics is dominated by utilitarian theories stemming from the tradition of the British empiricism of Jeremy Bentham, John Stuart Mill, and Henry Sidgwick. The representatives of this theory maintain that evaluation of moral acceptability of a particular activity must take into consideration the options available at the time of selection and assess the consequences of all possible acts. The general form of utilitarianism consists of two components: on the one hand, it is consequentialism (the correctness of activity is exclusively assessed by its consequences); on the other hand, consequentialism is completed with the criterion of rightness: the rightness of the consequences of our acts is determined by their utility (hedonism) or fulfillment or failure to fulfil our desires. Consequentialism excludes more traditional normative factors, such as the intention of the actor. Consequentialists do not usually speak of human rights. In their view, the notion of dignity and the related respect for a human being does not provide clear criteria for drawing normative conclusions (Černý, 2018).

The ethical theory of preferential utilitarianism represented by the Australian philosopher Peter Singer seeks the criterion of rightness in maximization of preferences defined broadly to also cover the preferences of persons who are not gifted with the ability of higher cognitive functions. Singer distinguishes two meanings of the term 'human being': it can refer to a member of the biological species Homo sapiens; it can mean a being who is defined functionally rather than ontologically (i.e., what the being is). Singer assumes that there is no inherent moral difference between killing and allowing to die. Singer believes that active euthanasia is the only truly moral option (Černý, 2012). 
We understand theoretical bioethical modeling as a comprehensive process that combines methods of general bioethics and an expert process of clinical bioethics. For a crisis/disaster situation, we prefer, from the perspective of general bioethics, the non-utilitarian model; medical ethics employs the ethics of uncertainty, situational, and nursing ethics. The main triage principles comprise maximization of benefits, justice, and autonomy, followed by equality and transparency. The main values are human dignity, multi-culture, and saved lives. Clinical bioethics employs an expert-ethical triage method. The global bioethical objective of general bioethics in the period of a pandemic crisis should be based on the paradigm of social solidarity and justice (fair change).

\section{Bioethical comparison of the differences in the approach to intensive care indication in the situation of crisis and limited capacities in Germany, Holland, Czech Republic, and Slovakia (Conclusions)}

A) The objective of the German recommendations is not to assess the value of human life. Priority-setting should enable the greatest possible number of patients to use (limited) medical resources. Saving human lives is specified in the Dutch and Czech bioethical documents. Slovak guidelines define utility in general terms, on the basis of health criteria. The number of saved lives, years of life, and years of good quality life are mentioned as options.

B) Respect for human beings is mentioned in the German, Dutch, and Slovak recommendations. While the notion of human dignity is emphasized in the Czech Standpoint of the ČSARIM (2020), it is absent in the recommendations of Czech bioethicists (Černý, Doležal \& Doležal, 2020).

C) Age as a criterion for denying intensive care is absent in the German and Slovak documents. It is proposed by Czech bioethicists (Černý, Doležal \& Doležal, 2020), not by Standpoint of the ČSARIM (2020). The Dutch recommendations talk in this regard about the principle of intergeneration solidarity in the sense of fair change.

D) The geriatric frailty index is mentioned in the German guidelines in the context of overall health condition evaluation for a long-term prognosis without numerical expression. The Dutch guidelines use frailty in expert evaluation criteria for providing acute care; ethical guidelines explicitly exclude it. Czech expert recommendations explicitly exclude it, too. The expert guidelines of the Slovak Ministry of Health mention frailty in the triage process under the condition of prioritizing the physiological frailty (without defining it). Furthermore, it is pointed out that a special evaluation is needed for an existing stabilized condition that affects the physical and other activities of a patient, and thus inappropriately influences the total score. For the process of triage, frailty is evaluated numerically according to the scale of serious diseases. The total score determines the selection of an acute, conservative, or palliative treatment.

1) The differences in the German, Dutch, Czech, and Slovak expert-ethical recommendations for intensive care indication in a crisis stem from the specific social-cultural environments, and are projected onto the particular legal systems and health care.

2) Triage-related decisions concerning the medically inappropriate treatment of the elderly based on a numerical evaluation (frailty index) would correspond with the functionalist definition of human being primarily not defined ontologically; intensive care indication would overlap with utilitarian preferences. Moreover, the decision of the medically inappropriate treatment of the elderly based on numerically defined frailty would violate the principles of equality and justice. Bioethics would assess it as a borderline situation overlapping with the utilitarian attitude to human dignity, human rights, and a 'good' death. We propose nonutilitarian ethics of social consequences as a solution to and illustration of a philosophical theory for medical bioethics in the situation of a disaster. The primary values of this ethics are humanity, human dignity, and moral rights. The secondary values comprise justice, 
responsibility, moral duty, and tolerance. Their task and purpose follow from their capacity to help in reaching and implementing the moral good (Gluchman, 2016).

Compared to preferential utilitarianism, non-utilitarian ethics compensates for the requirement of maximizing the benefits and non-discrimination of endangered groups of patients in the period of crisis and, therefore, reduces bioethical uncertainty.

3) The application of strict medical criteria for triage decisions for the sake of optimal effects can mean that some groups of patients lose any chances to save their life. This can be viewed as unfair: belonging to a high-risk group does not imply depriving a patient of intensive care. Full concentration on medical reasons for effective utilization of resources might increase health care inequality (Verweij et al., 2020).

Medical expert processes should define the criteria for the evaluation of patients based on the definition of a medically inappropriate treatment in which case the parameter of frailty is a part of a long-term prognosis, depending on limited or scarce resources.

4) A selected medical expert procedure must be followed by a bioethical process of consensual evaluation of the intensive care indication in the situation of a crisis and limited capacity. Neither age nor the parameter of frailty should be included in the bioethical triage process for the elderly. Age can be considered on the basis of intergeneration solidarity as a fair change. The legal situation in a crisis period cannot reflect the existing situation. Therefore, expert-ethical guidelines should be commented on by relevant professional organizations and institutions. In Slovakia, it is the Health Care Supervision Office. In an ideal case, the triage protocol should be an outcome of a politically legitimate process. The triage of patients in a pandemic crisis requires nationwide discussion.

\section{References}

ČSARIM (2015): Zásady a principy pro přijímání pacienti̊ na pracoviště intenzivní péče [Principles and guidelines for admitting patients to intensive care units]. In: Praktický lékaŕ, 95(4), pp. 186-187.

ČSARIM (2020): Stanovisko výboru Českej spoločnosti anesteziológie, resuscitácie a intenzívnej medicíny ČLS JEP s názvom Rozhodovanie u pacientov v intenzívnej. starostlivosti v situácii nedostatku vzácnych zdrojov [Standpoint of the Committee of the Czech society of anesthesiology, resuscitation and intensive care of the Czech Medical Association JEP entitled decision-making for patients in intensive care in a situation of lack of rare resources]. In: Anesteziologie a intenzívní medicína, 31(5), pp. 249-255.

ČERNÝ, D. (2012): Euthanasie a etika (1. část) Preferenční utilitarismus Petra Singera [Euthanasia and ethics (Part 1) Preferential utilitarianism of Peter Singer]. In: Časopis zdravotnického práva a bioetiky, 2(3), pp. 17-30.

ČERNÝ, D. (2018): Eutanazie a dobrý život: proč je eutanazie (někdy) morální [Euthanasia and the good life: why euthanasia is (sometimes) moral]. In: Vnitřni lékařství, 64(3), pp. 236244.

ČERNÝ, D., DOLEŽAL, A. \& DOLEŽAL, T. (2020): Etická a právnívýchodiska pro tvorbudoporučeni $k$ rozhodováni o alokacivzácnýchzdrojůpriposkytovánízdravotníchslužeb $v$ rámcipandemie COVID-19 [Ethical and legal bases for making recommendations for decisionmaking on the allocation of scarce resources in the provision of health services within the pandemic COVID-19]. Prague: Ústav státu a práva AV ČR, Kabinet zdravotnického práva a bioetiky.

DOLEŽAL, T., ČERNÝ, D., RUSINOVÁ, K. \& KUŘE, J. (2021): Odpověd'. Vyjádření k některým mediálním ohlasům a stanovisko ČSARIM 13/2020. Rozhodování u pacientů v intenzivní péči v situaci nedostatků vzácných zdrojů [Answer. Comments on some media responses and the opinion of ČSARIM 13/2020. Decision-making for patients in intensive care 
in a situation of scarcity of scarce resources]. In: Anesteziologie a intenzivní medicína, 32(2), pp 119-121.

GLUCHMAN, V. (2016): Disaster issues in non-utilitarian consequentialism (Ethics of social consequences). In: Human Affairs, 26(1), pp. 52-62.

CHRISTIAN, M. D., SPRUNG, C. L., KING, M. A., DICHTER, J. R., KISSOON, N., DEVEREAUX, A. V., GOMERSALL, C. D. \& TASK FORCE FOR MASS CRITICAL CARE (2014): Triage. Care of the critically ill and injured during pandemics and disasters. Consensus statement. In: CHEST Journal, 146(4), Supplement, pp. e61S-e74S.

JEDLIČKOVÁ, A. (2020): Etické konotace léčby onemocnění covid-19 [Ethical connotations of the treatment of COVID-19 disease]. In: Vnitřni lékařství, 66(7), pp. e8-e12.

DE GEER, L., FREDRIKSON, M. \& TIBBLIN, A. O. (2020): Frailty predicts 30-day mortality in intensive care patients. In: European Journal of Anaesthesiology, 37(11), pp. 1058-1065.

EHNI, H. J., WIESING, U. \& RANISCH, R. (2020): Saving the most lives-A comparison of European triage guidelines in the context of the COVID-19 pandemic. In: Bioethics, 35(2), pp. $125-134$.

FEINSTEIN, M. M., NIFORATOS, J. D., HYUN, I., CUNNINGHAM, T. V., REYNOLDS, A., BRODIE, D. \& LEVINE, A. (2020): Considerations for ventilator triage during the COVID-19 pandemic. In: The Lancet, 8(6), p. E53.

JÖBGES, S., VINAY, R., LUYCKX, V. A. \& BILLER-ANDORNO, N. (2020): Recommendations on COVID-19 triage: international comparison and ethical analysis. In: Bioethics, 34(9), pp. 948-959.

KUŘE, J. (2020): Etika rozhodování o zdravotní péči v závěru života [Ethics of decisionmaking about health care at the end of life]. In: Časopis zdravotnického práva a bioetiky, 10(2), pp. 84-104.

MARCKMANN, G., NEITZKE, G., SCHILDMANN, J., MICHALSEN, A., DUTZMANN, J., HARTOG, C., JÖBGES, S., KNOCHEL, K., MICHELS, G., PIN, M., RIESSEN, R., ROGGE, A., TAUPITZ, J., JANSSENS, U. (2020): Decisions on the allocation of intensive care resources in the context of the COVID-19 pandemic: Clinical and ethical recommendations of DIVI, DGINA, DGAI, DGIIN, DGNI, DGP, DGP and AEM. In: Medizinische Klinik Intensivmedizin und Notfallmedizin, 115(3), Supplement, pp. 115-122.

NVIC (2020): Draaiboek Pandemie, Deel 1 [Protocol Pandemics, Part 1]. Netherlands Association of Intensive Care, Versie 1.

NOVOTNÝ, R., NOVOTNÁ, Z. \& ANDRAŠČÍKOVÁ, Š. (2020): Inappropriate hemodialysis treatment and palliative care. In: Ethics \& Bioethics (in Central Europe), 10(1-2), pp. 48-58. MINISTRY OF HEALTH OF THE SLOVAK REPUBLIC (2020): Odborné usmernenie MZ SR o indikácii intenzívnej starostlivosti v situácii krízy z dôvodu pandémie ochorenia COVID19 [Bulletin of the Ministry of Health of the Slovak Republic: Professional guideline of the Ministry of Health of the Slovak Republic on the indication of intensive care in a crisis situation due to the COVID-19 pandemic]. In: Vestnik MZ SR, 69(1-4), pp. 2-17.

ŠUSTEK, P. \& ČERNÝ, V. (2021): Vyjádření k některým mediálním ohlasům a stanovisko ČSARIM 13/2020. Rozhodování u pacientů v intenzivní péči v situaci nedostatků vzácných zdrojů [Comments on some media responses and the opinion of ČSARIM 13/2020. Decisionmaking for patients in intensive care in a situation of scarcity of scarce resources]. In: Anesteziologie a intenzivní medicína, 32(2), pp 119-121.

WHITE, D. B., KATZ, M. H., LUCE, J. M. \& LO, B. (2009). Who should receive life support during a public health emergency? Using ethical principles to improve allocation decisions. In: Annals of Internal Medicine, 150(2), pp. 132-138.

WHITE, D. B. \& LO, B. (2020). A framework for rationing ventilators and critical care beds during the COVID-19 pandemic. In: JAMA, 323(18), pp. 1773-1774. 
VERWEIJ, M., VAN DE VATHORST, S., SCHERMER, M., WILLEMS, D. \& DE VRIES, M. (2020): Ethical advice for an intensive care triage protocol in the COVID-19 pandemic: Lessons learned from The Netherlands. In: Public Health Ethics, 13(2), pp. 157-165.

WHO (2020): Ethics and COVID-19: resource allocation and priority-setting. World Health Organization reference number: WHO/RFH/20.2. [online] [Retrieved August 31, 2021], Available at: https://www.who.int/ethics/publications/ethics-covid-19-resource-allocation.pdf? ua $=1$ 